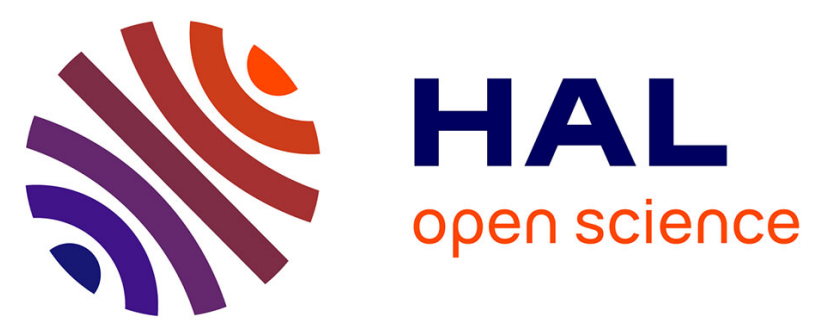

\title{
Live nearby, be different, work apart? Some learnings from action spaces discrepancies in Santiago de Chile
}

Florent Demoraes, Marc Souris, Yasna Contreras

\section{To cite this version:}

Florent Demoraes, Marc Souris, Yasna Contreras. Live nearby, be different, work apart? Some learnings from action spaces discrepancies in Santiago de Chile. Geographical Analysis, 2021, Special Issue: Neighborhood Effects and Neighborhood Dynamics, 53 (2), pp.329-354. 10.1111/gean.12232 . hal-02464601

\section{HAL Id: hal-02464601 \\ https://hal.science/hal-02464601}

Submitted on 15 Mar 2020

HAL is a multi-disciplinary open access archive for the deposit and dissemination of scientific research documents, whether they are published or not. The documents may come from teaching and research institutions in France or abroad, or from public or private research centers.
L'archive ouverte pluridisciplinaire HAL, est destinée au dépôt et à la diffusion de documents scientifiques de niveau recherche, publiés ou non, émanant des établissements d'enseignement et de recherche français ou étrangers, des laboratoires publics ou privés. 


\title{
Live nearby, be different, work apart? Some learnings from action spaces discrepancies in Santiago de Chile
}

\author{
Demoraes Florent ${ }^{1}$, Souris Marc², Contreras Yasna ${ }^{3}$ \\ ${ }^{1}$ UMR 6590 - Espaces et Sociétés (ESO), Université Rennes 2 / Centre National de la Recherche Scientifique \\ ${ }^{2}$ UMR 190 - Émergence des Pathologies Virales (EPV), Aix-Marseille Univ / IRD / Inserm / EHESP / IHU Méditerranée Infection \\ ${ }^{3}$ Departamento de Geografía, Facultad de Arquitectura y Urbanismo, Universidad de Chile
}

\begin{abstract}
This article examines macro-level contextual parameters and individual-based factors deemed in the literature to directly influence individuals' daily mobility practices. It considers urban structure, place of residence, situation in the social hierarchy, and position in the life course. Taking its inspiration from approaches highlighting segregation at destination place and studies focusing on mobility biographies, it enquires whether systematic discrepancies may be detected between the places frequented for work or study on a daily basis by groups of individuals residing in the same neighborhood. It also looks at whether home location (in a central area, inner suburb, or outskirt) influences how action spaces are configured. The analysis relies on a three-phase integrated method. First, a typology of individuals is assembled so as to put together homogenous socio-demographic groups. Second, the action spaces of these groups are calculated and mapped. Third, the significance of spatial differences in action spaces is assessed using a bivariate colocation test, hitherto used primarily in spatial epidemiology. This three-phase method is applied to data collected in Santiago de Chile during a survey of 1000 households, designed to capture spatial mobility from a biographical perspective.
\end{abstract}

\section{Key word}

Spatial mobility, Action spaces, Bivariate co-location test, Santiago de Chile

\section{Résumé}

Cet article examine un ensemble de paramètres contextuels et de facteurs individuels qui apparaissent dans la littérature comme influençant directement les pratiques quotidiennes de mobilité des individus. II considère la structure urbaine, le lieu de résidence, la position des individus dans la hiérarchie sociale et le cycle de vie. S'inspirant d'approches mettant en évidence la ségrégation sur le lieu de destination et d'études sur la mobilité appréhendée dans une perspective biographique, il cherche à voir si des divergences systématiques peuvent être détectées entre les lieux fréquentés quotidiennement pour le travail ou les études par des groupes d'individus résidant dans un même quartier. Il cherche également à savoir si la localisation du domicile (dans une zone centrale, une proche banlieue ou une périphérie) influence la configuration des espaces d'action. L'analyse repose sur une méthode en trois phases. Tout d'abord, une typologie des individus est établie de manière à constituer des groupes sociodémographiques homogènes. Ensuite, les espaces d'action de ces groupes sont calculés et cartographiés. Troisièmement, la significativité des différences spatiales entre les espaces d'action est évaluée à l'aide d'un test de colocalisation bivarié, utilisé jusqu'à présent principalement en épidémiologie spatiale. Cette méthode est appliquée à des données recueillies à Santiago du Chili lors d'une enquête auprès de 1000 ménages, conçue pour saisir la mobilité spatiale sous un angle biographique.

\section{Mots-clefs}

Mobilité spatiale, Espaces d'action, Test de co-localisation bivarié, Santiago du Chile 


\section{Resumen}

En este artículo se examina un conjunto de parámetros contextuales y factores individuales que aparecen en la bibliografía como los que influyen directamente en las prácticas cotidianas de movilidad de los individuos. Considera la estructura urbana, el lugar de residencia, la posición de los individuos en la jerarquía social y el ciclo de vida. Basándose en enfoques que ponen de relieve la segregación en el lugar de destino y en estudios sobre la movilidad desde una perspectiva biográfica, trata de ver si se pueden detectar discrepancias sistemáticas entre los lugares frecuentados diariamente para el trabajo o el estudio por grupos de personas que viven en el mismo barrio. También trata de determinar si la ubicación de la vivienda (en una zona central, un suburbio cercano o una periferia) influye en la configuración de los espacios de acción. El análisis se basa en un método de tres fases. En primer lugar, se establece una tipología de individuos para formar grupos sociodemográficos homogéneos. Luego se calculan y cartografían los espacios de acción de estos grupos. En tercer lugar, la importancia de las diferencias espaciales entre los espacios de acción se evalúa mediante una prueba de colocación bivariada, que hasta ahora se ha utilizado principalmente en la epidemiología espacial. Este método se aplica a datos recogidos en Santiago de Chile en una encuesta de 1000 hogares, diseñada para captar la movilidad espacial desde una perspectiva biográfica.

\section{Palabras clave}

Movilidad espacial, Espacio de acción, Prueba de co-localización bivariada, Santiago de Chile

\section{Introduction}

\section{Urban structure, place of residence, and mobility practices}

Over recent decades, the influence of urban structure and residential location on daily mobility practices and travel behavior has been the subject of numerous studies looking at data from all continents (Horton and Reynolds 1971; Cullen and Godson 1975; Simpson 1987; Gordon et al. 1989; Giuliano and Small 1993; Cervero and Wu 1997; Aguiléra and Mignot 2002; Lévy and Dureau 2002; Berger 2004; Buliung and Kanaroglou 2006; Baccaïni et al. 2007; Parthasarathi et al. 2015). These interactions have been analyzed in several long-range integrated land use and transport models. Work by Wegener (2011), for example, considers how long-term and mid-term household decisions may influence place of residence and of work, together with car ownership, in the Ruhr region, a densely populated area in Germany characterized by a tradition of regulated land planning. These interactions have also been studied for urban areas in other regions, such as Latin America, where cities share certain characteristics, tending to be low density, very spread out, and with deep social inequalities (Schteingart 2001; Kilroy 2007; Carman et al. 2013). They are also characterized by strong socio-residential segregation and informal urbanization (Lungo and Baires 2001; Rodríguez and Arriagada 2004; Sabatini et al. 2001; Capron and González Arellano 2006). The "fragmented" or polycentric layout of these cities means that resources are unequally distributed across the metropolitan areas (Prévôt Schapira 2000; Borsdorf 2003; Capron and González Arellano 2006), and professional opportunities are clearly not distributed homogenously. Certain scholars (Antico 2003; Dureau 2006; Rodríguez 2007; Rodríguez 2008; Jouffe 2011; Hernández 2012; Segura 2012; Jirón et al. 2010; Cosacov 2015; Suárez et al. 2016) have shown that this Latin American urban model places major constraints on their inhabitants' daily mobility. Commutes are generally longer, take more time, and are much more expensive for households living far away from the inner city, as many cities still lack an integrated transport system (Moreno 2016). Moreover, the level of public transport service is generally much lower and more informal in the outskirt. It thus now seems quite clear that urban structure, notably in Latin America, has a direct influence on individuals' daily mobility practices, and that destination places differ depending on individuals' socio-demographic profile and place of residence. 


\section{The study of daily mobility from a biographical perspective}

As seen in the previous section, urban structure and residential location, both macro-level contextual parameters, influence daily mobility practices. But individual-based factors likewise affect travel behaviors which change over the life course, as well as, generally, when people move home. As Scheiner et al. (2013) indicate, "in recent years a growing body of research has emerged that focuses on changes in travel mode choice, travel distances, car ownership and other measures of travel demand over the life course of an individual". By using a life course approach, one may better apprehend residential choices resulting from mature decisions over the medium or long term (unions, births, etc.), together with those stemming from sudden or more gradual breaks in the family cycle (nest-leaving transitions, separations, deaths, etc.) or career (job loss or retirement), where these residential choices impact on daily mobility practices, as seen in the previous section. In 2003, Lanzendorf proposed the concept of "mobility biographies". This refers to "the total of an individual's longitudinal trajectories in the mobility domain and assumes that key events in these trajectories exist or, in other words, that at certain moments in an individual's life, daily travel patterns, car ownership or other mobility characteristics change to an important degree". In addition to key events, the stage in the life course is likewise decisive for understanding people's daily mobility practices (Camstra 1994; Camstra 1996; Depeau 2001; Morency et al. 2011; Demoraes et al. 2012; Demoraes et al. 2019). Against the backdrop of an ageing population, a growing number of studies have focused on the mobility of older people and on how their living spaces change over time (Alsnih and Henscher 2003; Rapoport 2005; Föbker and Grotz 2006; Lord et al. 2009; Lord et al. 2011; Quiroga 2014). Biographical perspective studies of daily mobility in Latin America are more recent. Delaunay (2010) measures changes in daily mobility in Santiago de Chile depending on occupational category and position in the life course. Pérez López and Capron (2018) put forward a gender-based analysis of changes of car usage over the life course in the Metropolitan Area of México. Mention may also be made of works based on two surveys carried out in Bogotá (Colombia) to assess "spatial mobility" from a biographical perspective (Dureau et al. 2015b). The design of these surveys was based on work by the GRAB research group. ${ }^{1}$ Spatial mobility refers to a set of movements in physical space by individuals or groups of individuals, no matter the duration or distance of these movements (Zelinsky 1971; Bassand and Brulhardt 1980; Courgeau 1988). Based on these two surveys carried out in Bogotá, Demoraes et al. (2018) examines how accessibility to places of activity in this city evolved between 1993 and 2009 for co-resident individuals as a function of their stage in the life course (whether they were children, students, or adults).

\section{The concept of action space and ways of mapping it}

The spatial dimension of mobility practices has been extensively studied using the concept of action space, also referred to as activity space (Von Dürckheim 1932, cited in Dijst 1999; Horton and Reynolds 1971; Golledge and Stimson 1997). According to Dijst (1999), the actual action space is "the spatial unit in which activity places are located which have been visited by a person during some period of time". Most often, action spaces are defined at an individual level (Schönfelder and Axhausen 2002; Hirsch et al. 2014; Jones and Pebley 2014). The characteristics of individual action spaces (the number of places frequented, frequency of visits to each place, distance from home, size and shape of the action space, etc.) are then generally summarized or categorized (Lord et al. 2009; Hirsch et al. 2014). Action spaces can also be defined at an aggregate level, for groups of individuals (Raine 1978; Janelle and Goodchild 1983; Buliung and Kanaroglou 2006; Demoraes et al. 2012; Quiroga 2014). Raine (1978), for instance, analyzes respondents' activity patterns for six sites in Cardiff in order to gauge how the typical patterns for any given site compare to those of the other sites.

There are various ways of mapping action space. The choice is determined by the nature of the input data, depending on whether the spatial point pattern describes the daily trips with high spatial granularity (such as data based on mobile phone positions, travel diaries, or GPS traces) or not (geocoded destination places 
with no details about the path taken to reach them). Based on a six-week travel diary survey conducted in two German cities in 1999, Schönfelder and Axhausen (2003) assess three methods for visualizing individual activity spaces (confidence ellipse, kernel density estimates, and shortest path networks). Rai et al. (2007) identifies four parametric geometries (ellipses, superellipses, Cassini ovals, and bean curves) for capturing a specific share of locations visited, namely 95\%, while minimizing the area covered. These advanced methods were applied to five long-duration diaries and GPS observations. For an extensive review of the methods that may be used for visualizing action spaces (standard deviational ellipses, travel probability fields, kernel density estimation, minimum convex-hull polygons, network-based buffer approaches, etc.), see Patterson and Farber (2015), Kwan et al. (2019) and Vich et al. (2017).

\section{Action spaces as an indicator of social exclusion and segregation}

One frequent use of the concept of action space is as an indicator of social exclusion and segregation. As Zhang et al. (2019) indicates, "people experience segregation not only in their residential places but also in other places where they undertake daily activities, such as the workplace and sites for non-work activities". A growing number of researchers have looked at this topic for many countries (Jirón 2009; Åslund and Skans 2010; Palmer 2013; Wang et al. 2012; Jones and Pebley 2014; Farber et al. 2015). Many works compare the spatial characteristics of individuals' activity spaces in order to characterize segregation between social or ethnic groups (Janelle and Goodchild 1983; Schnell and Yoav 2001; Schönfelder and Axhausen 2003; Atkinson and Flint 2004; Ellis et al. 2004; Wong and Shaw 2011; Farber et al. 2012; Silm and Ahas 2014; Järv et al. 2015; Li and Wang 2017). These studies do not all employ the main mapping techniques discussed in the previous section, since they often rely on individual-level data that is hard to synthesize on a map. Several authors use data aggregated in spatial units (Ellis et al. 2004; Wong and Shaw 2011). Some studies do not provide maps of any kind (Åslund and Skans 2010; Atkinson and Flint 2004; Li and Wang 2017). The study areas also vary greatly in size (the whole country, a set of cities, a single entire city, or a set of urban districts). These studies also draw on diverse methodologies to compare the action spaces (a general linear model, composite indices, regressions, location quotient, centrographic analysis, dissimilarity measurements, metric of social interaction potential, person-specific and location-specific measure of exposure inspired by the $\mathrm{G}_{i}{ }^{*}$ statistics, etc.). Additionally, it may be noted that a time-geographical approach is now increasingly used, in order to reveal how segregation at destination changes over the course of the day, or between day and night (Palmer 2013; Farber et al. 2015; Le Roux et al. 2017; Park and Kwan 2018).

\section{Discrepancies between the action spaces of socio-demographic groups: key questions}

As we have seen, macro-level contextual parameters and individual-based factors both have a direct influence on individuals' daily mobility practices. So far, we have considered urban structure, place of residence, and individuals' position in the social hierarchy and in the life course. But do these parameters always lead to differences in destination places? In other words, are there clear, systematic discrepancies in how socio-demographic groups interact with a metropolitan area on a daily basis? If so, how are we to assess the significance of such differences? Do certain groups stand out? If so, what might the explanatory factors be? How does home location (in a central area, inner suburb, or outskirt) influence the way action spaces are configured?

This study addresses these issues based on the results of a survey conducted in Santiago de Chile, a widespread, low-density, highly segregated city. We also look at how public policies could take advantage of such new knowledge. We start by introducing the study area, then detail the dataset and method used, before finally presenting the main results. 


\section{Study area: the Santiago Metropolitan Area}

The Santiago Metropolitan Area (SMA) is composed of 39 communes (Fig. 1), with 6.03 million inhabitants according to the 2012 census, amounting to $36.4 \%$ of the national population. ${ }^{2}$ The Santiago Metropolitan Region (SMR, with 52 communes) is home to $40.4 \%$ of the national population, and produces $44.4 \%$ of the country's GDP. Spatial distribution analysis of production facilities in the SMA shows that economic activities are not uniformly distributed. Jobs are mainly concentrated in the central space (the commune of Santiago) and the north-east sector (comprising the communes of Providencia, Las Condes, and Vitacura). Primary and secondary schooling (both public and private) is distributed in broadly homogenous fashion. The universities are located in the center and north-east of the SMA. The SMA has particularly marked social divisions (Rodriguez and Arriagada 2004; Rodriguez 2007; Demoraes et al. 2010; Demoraes et al. 2011).

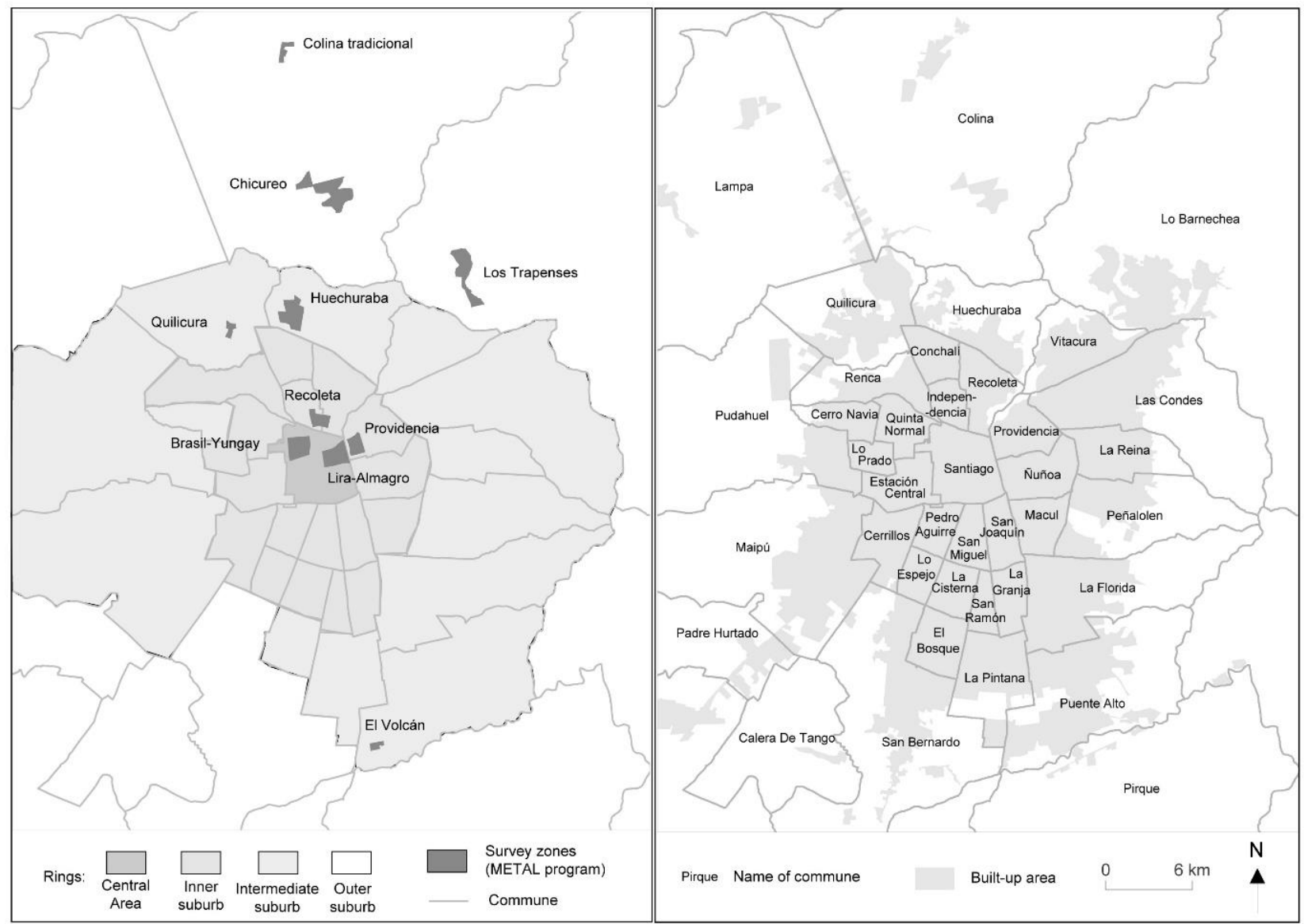

Figure 1. Santiago Metropolitan Area communes, rings, and ANR METAL program survey zones (2009). Source: adapted from Dureau et al., 2015: 81 - INE data (communes), Observatorio de Ciudades de la Universidad Católica (built-up area) and Google Earth (survey zones).

As indicated in figure 2, showing the household social condition index based on the 2002 census data (the last available census before the METAL surveys were carried out in 2009), ${ }^{3}$ the wealthy classes were concentrated in the north-east of the SMA. As for the south of the SMA, it is at the opposite end of the social hierarchy, with working-class districts and a high concentration of social housing, even though there have been middle-class property developments there since the 1990s (Contreras 2011; Contreras et al. 2016). 


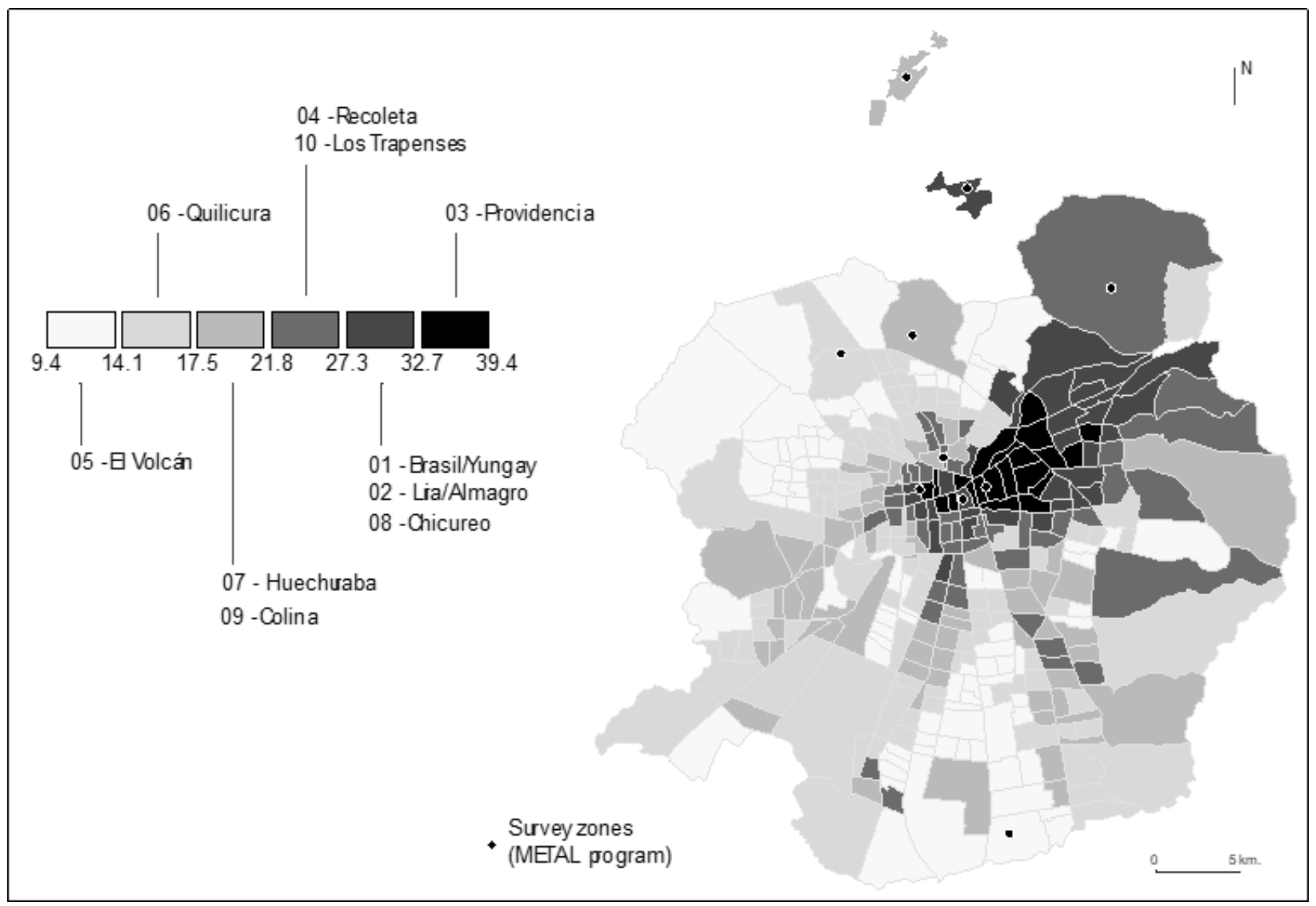

Figure 2. Position of the ANR METAL program survey zones (2009) with respect to the average social condition index per district (Santiago Metropolitan Area). Source: adapted from Dureau et al. (2015a: 134) based on INE data (2002 census). Source: adapted from Dureau et al. (2015a: 134) based on INE data (2002 census).

Like many Latin American metropolises, the SMA has seen a sharp increase in daily mobility over the past two decades. The number of journeys per person rose from 1.8 in 1991 to 3 in 2006 (Table 1). Over the same period, the number of cars increased at an average annual rate of $4.1 \%$ (SECTRA), and the proportion of car journeys rose sharply from $15.6 \%$ to $27.6 \%$.

Table 1. Changes in daily mobility between 1991 and 2006 in Santiago. Source: adapted from Gouëset et al. (2015: 30)7 based on: Encuesta Origen Destino de Viajes del Gran Santiago, 1991; Encuesta de Movilidad para el Gran Santiago, 2006

\begin{tabular}{|l|c|c|c|}
\hline & 1991 & 2006 & $\begin{array}{c}\text { Average annual rate of } \\
\text { variation (\%) - 1991-2006 }\end{array}$ \\
\hline Number of journeys per week day (in millions) & 6 & 17.9 & 7.1 \\
\hline Number of journeys per person & 1.8 & 3 & 3.2 \\
\hline Total number of cars & 404,769 & 766,451 & 4.1 \\
\hline Motorization rate (number of cars per 100 households) & 34 & 49 & 2.3 \\
\hline Proportion of car journeys & 15.6 & 27.6 & 3.6 \\
\hline
\end{tabular}

The SMA has a network of fast toll roads, and a metro network with 98 stations and $92.5 \mathrm{~km}$ of track. In 2007 a bus rapid transit (BRT) system was launched, known as the Transantiago. This system, based on buses travelling on dedicated lanes along certain sections, does not cover the entire SMA. It does however have the advantage of providing a service that is integrated with the metro, including integrated ticketing. 


\section{Material and methods}

\section{Dataset}

This article draws on data collected in a survey of 1004 households (3501 individuals) in ten study zones in Santiago de Chile. This survey was carried out between June and September 2009 as part of the ANRfunded METAL program. ${ }^{4}$ There were three main components:

- a global approach to mobility practices irrespective of distance (intra-urban, regional, or international ranges) or duration (from daily trips to migrations);

- a biographical approach, in order to understand how individuals combine different forms of mobility over the course of their life in relation to their professional and family backgrounds;

- $\quad$ an approach repositioning individuals within their family and social network.

Given the purpose of the survey (to arrive at an overall understanding of all forms of mobility in relation to the life course) and the limits on the information that can be collected in a reasonable time using a questionnaire (each household survey took an average of one and a half hours to complete), sequences within any given journey were not recorded. We therefore do not have details about the routes in the city, only about the final destinations where the activities took place. For the same reasons, the various places individuals visited for different purposes over the course of a day were not recorded either.

However, this dataset remains very valuable because it is without equivalent for Chile. Indeed, as in many countries one of the restrictions on studying daily mobility in Chile relates to data collection tools, mainly origin-destination surveys and, to a lesser extent, population and housing censuses. Broadly speaking, they provide global knowledge about daily trips (frequency, intensity) by age, gender, mode of transport, travel purpose, and duration. They also provide information about household car ownership rates. These data collection tools have the advantage of being representative of the whole city, and of being applied regularly (generally every ten years) using a broadly standard methodology, allowing for diachronic analysis. The results are used, among other purposes, to adapt public transport systems and as input for traffic models. Yet while characterizing effective travel, OD surveys do not provide information such as the residential trajectory of individuals, or information about their biography, thus limiting interpretation of mobility practices (Delaunay et al. 2013: 14). Ultimately, OD surveys and censuses are of limited hermeneutic value for it is not always possible to access individual data (microdata). For Chile, as for many countries, only aggregate data are available, in which combinations of predefined variables are already partitioned into classes.

This article analyzes just one subset of the METAL survey, namely data collected about daily commutes between home and place of activity (work or study) together with individual characteristics from the survey's biographical component. Home-to-work or home-to-study trips are by far the most frequent type of travel, accounting for $69 \%$ of trips from home when the METAL survey was conducted (SECTRA, 2006). They act as a daily marker of how a metropolitan area functions, illustrating the specific spatial configuration of employment and education provision. The individual characteristics derived from the biographical component enable us to define where individuals are situated in their education, career, and residential trajectory.

\section{Survey zones}

Ten study zones were selected to provide an illustrative mosaic of the socio-economic profiles, housing conditions, and urbanization phases of the Santiago Metropolitan Area. Two study zones lay in the commune of Santiago in the center, two in the inner suburbs to the north and east, and the remaining six in the intermediate and outer suburbs to the north and south (see Fig. 1). They show the wide range of daily mobility strategies inhabitants use to access urban resources. As indicated in table 2, a number of 
zones are home to populations with heterogeneous socio-demographic characteristics (the Brasil/Yungay survey zone), while others displayed far less diversity, such as the wealthy neighborhoods of Chicureo and Los Trapenses, and the poor neighborhood of El Volcán. The households in each zone were selected using a two-stage area sampling frame (blocks and households), following the method developed by Dureau et al. (1989).

Table 2. Characteristics of the zones selected for the ANR METAL program survey in Santiago in 2009 - Source: adapted from Dureau et al. (2015c: 80) - NB: mw: minimum wage (165,000 Chilean pesos)

\begin{tabular}{|c|c|c|c|c|c|c|c|c|c|c|c|}
\hline \multirow[b]{2}{*}{ Survey zone } & \multicolumn{2}{|c|}{ Central area } & \multicolumn{2}{|c|}{ Inner suburb } & \multicolumn{3}{|c|}{ Intermediate suburb } & \multicolumn{3}{|c|}{ Outer suburb } & \multirow[b]{2}{*}{$\begin{array}{l}\text { Total or } \\
\text { average }\end{array}$} \\
\hline & $\begin{array}{c}\text { Brasil- } \\
\text { Yungay }\end{array}$ & \begin{tabular}{|c|} 
Lira- \\
Almagro
\end{tabular} & Providencia & Recoleta & \begin{tabular}{c|} 
El \\
Volcán
\end{tabular} & Quilicura & Huechuraba & Chicuero & \begin{tabular}{c|} 
Colina \\
tradicional
\end{tabular} & \begin{tabular}{|c|} 
Los \\
Trapenses
\end{tabular} & \\
\hline $\begin{array}{l}\text { Name of } \\
\text { commune }\end{array}$ & \multicolumn{2}{|c|}{ Santiago } & Providencia & $\begin{array}{c}\text { Recoleta/ } \\
\text { Indepen- } \\
\text { dencia }\end{array}$ & $\begin{array}{l}\text { Puente } \\
\text { Alto }\end{array}$ & Quilicura & Huechuraba & Colina & Colina & $\begin{array}{c}\text { Lo } \\
\text { Barnechea }\end{array}$ & \\
\hline \multicolumn{12}{|c|}{ SAMPLE } \\
\hline $\begin{array}{l}\text { Number of } \\
\text { households }\end{array}$ & 140 & 121 & 90 & 132 & 82 & 132 & 89 & 60 & 98 & 60 & 1,004 \\
\hline Number of people & 420 & 346 & 256 & 425 & 297 & 523 & 351 & 227 & 378 & 290 & 3,513 \\
\hline \multicolumn{12}{|c|}{ TRANSPORT CONDITIONS (\% people using ...) } \\
\hline $\begin{array}{l}\text { Private vehicle (>= } \\
1 \text { time/week) }\end{array}$ & 40 & 30 & 47.6 & 21.1 & 16.2 & 56.7 & 50.5 & 91.7 & 38.3 & 84.7 & 41.4 \\
\hline $\begin{array}{l}\text { Public transport } \\
\text { (>= } 2 \text { times/week) }\end{array}$ & 77.5 & 83.2 & 66.4 & 60.8 & 85.9 & 73 & 77.7 & 23.6 & 44.4 & 38.8 & 70.1 \\
\hline \multicolumn{12}{|c|}{ SOCIO-DEMOGRAPHIC CONDITIONS } \\
\hline $\begin{array}{l}\text { Average } \\
\text { household size }\end{array}$ & 2.9 & 2.9 & 2.9 & 3.3 & 3.7 & 3.8 & 3.8 & 3.8 & 3.7 & 4.2 & 3.2 \\
\hline $\begin{array}{l}\% \text { single } \\
\text { households }\end{array}$ & 19 & 18.9 & 18.5 & 9.9 & 9.5 & 1.4 & 3.1 & 5 & 1.4 & 0 & 12.1 \\
\hline $\begin{array}{l}\text { \% households }>=6 \\
\text { people }\end{array}$ & 2.9 & 1.6 & 3.8 & 2.1 & 7.6 & 1.8 & 10.1 & 8.3 & 4.5 & 7.4 & 3.7 \\
\hline \multicolumn{12}{|c|}{ HOUSEHOLD INCOME LEVEL (\% household) } \\
\hline Low $(<1 \mathrm{mw})$ & 17.3 & 34.0 & 19.8 & 42.3 & 61.2 & 20.1 & 20.8 & 8.3 & 47.7 & 0.0 & 28.1 \\
\hline $\begin{array}{l}\text { Average-low (1-2 } \\
\mathrm{mw})\end{array}$ & 30.6 & 30.1 & 28.0 & 41.0 & 27.8 & 28.4 & 38.9 & 10.0 & 20.7 & 0.8 & 28.8 \\
\hline Average (2-5 mw) & 28.8 & 16.6 & 25.4 & 7.2 & 8.2 & 45.4 & 20.1 & 5.0 & 7.0 & 0.0 & 20.5 \\
\hline $\begin{array}{l}\text { Average-high and } \\
\text { high (>5 } 5 \mathrm{mw})\end{array}$ & 23.3 & 19.3 & 26.8 & 9.4 & 1.8 & 6.1 & 20.3 & 76.7 & 24.5 & 99.2 & 22.6 \\
\hline
\end{tabular}

\section{Methods}

A three-phase method was developed to analyze spatial differences in the places visited for work or study. First, a typology of individuals was assembled so as to put together homogenous socio-demographic groups. Second, the action spaces of these groups were calculated and mapped. Third, the significance of spatial differences in action spaces was analyzed using a statistical test for spatial colocation.

\section{Defining a socio-demographic typology of individuals using factor analysis and classification}

The first phase was to classify individuals into homogenous groups. This was done using multiple correspondence analysis (MCA), followed by hierarchical ascendant classification (HAC). ${ }^{5}$ A set of characteristics were selected to position individuals in their life course and social hierarchy. These characteristics were gender, age, activity (study or work), number of years spent in the dwelling, occupant status (owner, tenant, etc.), level of education, and level of household income. Seven classes were retained (see Table 3), ${ }^{6}$ and from these seven classes sixty-three groups were identified across the ten study zones. Each group thus equates to a set of people belonging to the same socio-demographic class 
and residing in the same zone. A detailed description of the typological analysis, including the categories for each active variable, the individuals' factor map, and the definition of each class by the variables based on the v-test, is provided in Demoraes et al. (2016).

Class A is composed of under-12s at school. They are "primary schoolchildren". Class B is made up of young people (12-24 years old) who study (in secondary or higher education) from modest backgrounds (lowincome households with less than 250,000 pesos i.e. USD360 per month). They are "young people in studies from modest backgrounds". Class C is comprised of young tenants (25-39 years old) having attended secondary school, who have recently moved into their accommodation, with low-to-average income (of 250,000 to 500,000 pesos i.e. USD360 to USD710 per month). They are "young working tenants with little education and fairly limited purchasing power".

Table 3. Spread of individuals* (who work or study) by socio-demographic class. Source: METAL survey, 2009 - Santiago

\begin{tabular}{|l|l|r|r|}
\hline Class & lass name & Number of people & Percentage (of total number) \\
\hline A & Primary schoolchildren & 168 & 11.2 \\
\hline B & Young people in studies from modest backgrounds & 362 & 24.2 \\
\hline C & $\begin{array}{l}\text { Young working tenants with little education and fairly limited } \\
\text { purchasing power }\end{array}$ & 255 & 17.0 \\
\hline D & Educated young workers with fairly high purchasing power & 98 & 6.6 \\
\hline E & Working property owners over forty & 363 & 24.3 \\
\hline F & Wealthy individuals & 156 & 10.4 \\
\hline G & Working senior citizens & 94 & 6.3 \\
\hline & & 1496 & 100 \\
\hline
\end{tabular}

Class D corresponds to young workers (25-39 years old) with average-to-high income (of 800,000 to $1,500,000$ pesos, i.e. USD1140 to USD2140 per month) with a high level of education. They are "educated young workers with fairly high purchasing power". Class E contains workers aged between 40 and 59 who have lived for over twenty years in their dwelling, which they own. They are "working property owners over forty". Class $\mathrm{F}$ is of people with the highest income (over 3,000,000 pesos, i.e. USD4270 per month), with higher education and who own their accommodation. They are "wealthy individuals". Lastly, class G is composed of elderly workers with secondary schooling, who have lived for over twenty years in their accommodation. They are "working senior citizens".

\section{Mapping action spaces using standard deviational ellipses (SDE)}

The second phase was to map each group's action space. As mentioned earlier, only places visited by individuals on a daily basis for their work or study (primary schooling, secondary schooling, and further education) were taken into consideration, each individual thus being associated with only one destination. To locate each place, the centroid of the destination commune was used. This geographic level is an acceptable way of locating these places, given that the communes are small in size $\left(16.8 \mathrm{~km}^{2}\right.$ on average for urbanized parts of the metropolitan area) and that our final cartographic plotting scale covers the whole metropolitan area $\left(2657 \mathrm{~km}^{2}\right)$.

Among the various mapping techniques discussed earlier to visualize and compare action spaces, we opted for standard deviational ellipses (SDE) obtained from a centrographic analysis (Lefever 1926; Bachi 1963), for three reasons. First, because it is adapted to our input data, namely, spatial point patterns with low granularity representing the destination locations for each group of individuals. Second, because SDEs precisely summarize the average position of a spatial point pattern through a mean or median center and 
symbolize its extent. For this reason, minimum convex-hull polygons were not used because they connect the most excentric points without taking the distribution of the other points into account, thus tending to exaggerate the extent of action spaces. Another advantage of SDEs is that they are not sensitive to microvariations in the position of points. Thus ultimately the fact that destination places were not recorded at district level (a more disaggregated geographic level than communes) is not problematic when using this method. Third, because SDEs provide a way of displaying the action space of a number of groups (about sixty in our case) on a single map (see Fig. 4), which avoids producing a large number of maps. That is why kernel density estimation was not suitable for the needs of our analysis. Additionally, SDEs are vector objects with associated metrics (such as areas) which can then be easily compared using, for example, an ellipse overlap index (Table 5). ${ }^{7}$

It should be noted that it was not possible to locate every destination place. This limitation related primarily to journeys to work. There are three reason for this. First, some of the individuals left the metropolitan area each day. Second, some had a profession that was difficult to locate (street vendors, sales representative, etc.). Third, problems were encountered during data capture and subsequent encoding. ${ }^{8}$ Out of the initial sample of 1,978 individuals, the final located sample numbered 1,496 individuals (Table 3), which is still sufficient to map and compare their action spaces.

In order to represent an action space with an SDE, a large enough group is needed, otherwise the ellipse will not be meaningful (a limitation already mentioned in Imbert et al. 2009). Certain categories of individuals were largely lacking in certain zones, or absent even. Ellipses were only calculated when there were at least five or more people in a group, ${ }^{9}$ hence 57 ellipses were calculated and mapped in all (see Fig. 4). Lastly, it should be stressed that working with different group sizes is not an obstacle to comparing ellipses, for the ellipse size does not depend on the underlying number of individuals. Indeed, the BravaisPearson correlation coefficient between the number of individuals per group and the area of the related ellipses is low $(\mathrm{R}=0.29)$.

\section{Assessing the significance of the differences between action spaces using a bivariate colocation test}

The third phase was to assess the significance of the differences between action spaces. As seen earlier, this is a common feature in studies seeking to detect segregation at activity place. Action spaces can be modeled as two-dimensional objects, thus a spatial statistical test was used. More specifically, we selected a bivariate colocation test presented in a spatial epidemiology journal (Souris and Bichaud 2011). This test ascertains whether the points in one spatial distribution are close overall to points in a second spatial distribution. The authors applied this colocation test to check if two diseases (Leishmania and Toscana) were spatially congruent in the city of Marseille (France). We selected this test for our study because it seemed well suited to checking any discrepancies between the action spaces associated with the groups described earlier. A formal description of this test, detailed in Souris (2019: 135-136), is summarized below.

This test works on the following principles. Let S1 represent a set of N1 locations, S2 a set of N2 locations. Each location is characterized by a Boolean mark (0 or 1). P1 is the set of positive locations in S1, and P2 the set of positive locations in S2. In our case, P1 represents the destination places of the individuals belonging to group 1, and P2 the destination places of the individuals belonging to group 2 . First, the Euclidian distance between each destination place from group 1 and its closest destination place from group 2 is calculated. Second, the mean of these distances is computed. This mean is hereafter referred to as the index. ${ }^{10}$

Two hypotheses can be stated: 
- a null hypothesis H0: the observed index cannot be differentiated from the indices obtained by a random spatial distribution of the positive marks;

- an alternative hypothesis HA: the probability of obtaining the observed index by chance is lower than a determined $\alpha$ value ( 0.05 for instance).

The statistical distribution of the index under the $\mathrm{HO}$ hypothesis is estimated using a Monte Carlo simulation (4000 iterations): at each iteration, the P2 destination places are randomly permuted among S2, which refers to all possible destinations, and the index is calculated using the P1 original locations. The probability of the observed index can be inferred from this estimated statistical distribution. The null hypothesis $(\mathrm{HO})$ is rejected if the probability of the observed index is lower than the $\alpha$ value, which equates to a risk of wrongly rejecting $\mathrm{HO}$ (Type I Risk). Figure 3 illustrates the principle of the test starting from (1) an observed situation exhibiting spatial similarity between both point patterns ( $\mathrm{HO})$, and (2) the two first iterations of the Monte Carlo simulation which return $\mathrm{H} 1$ in this example.
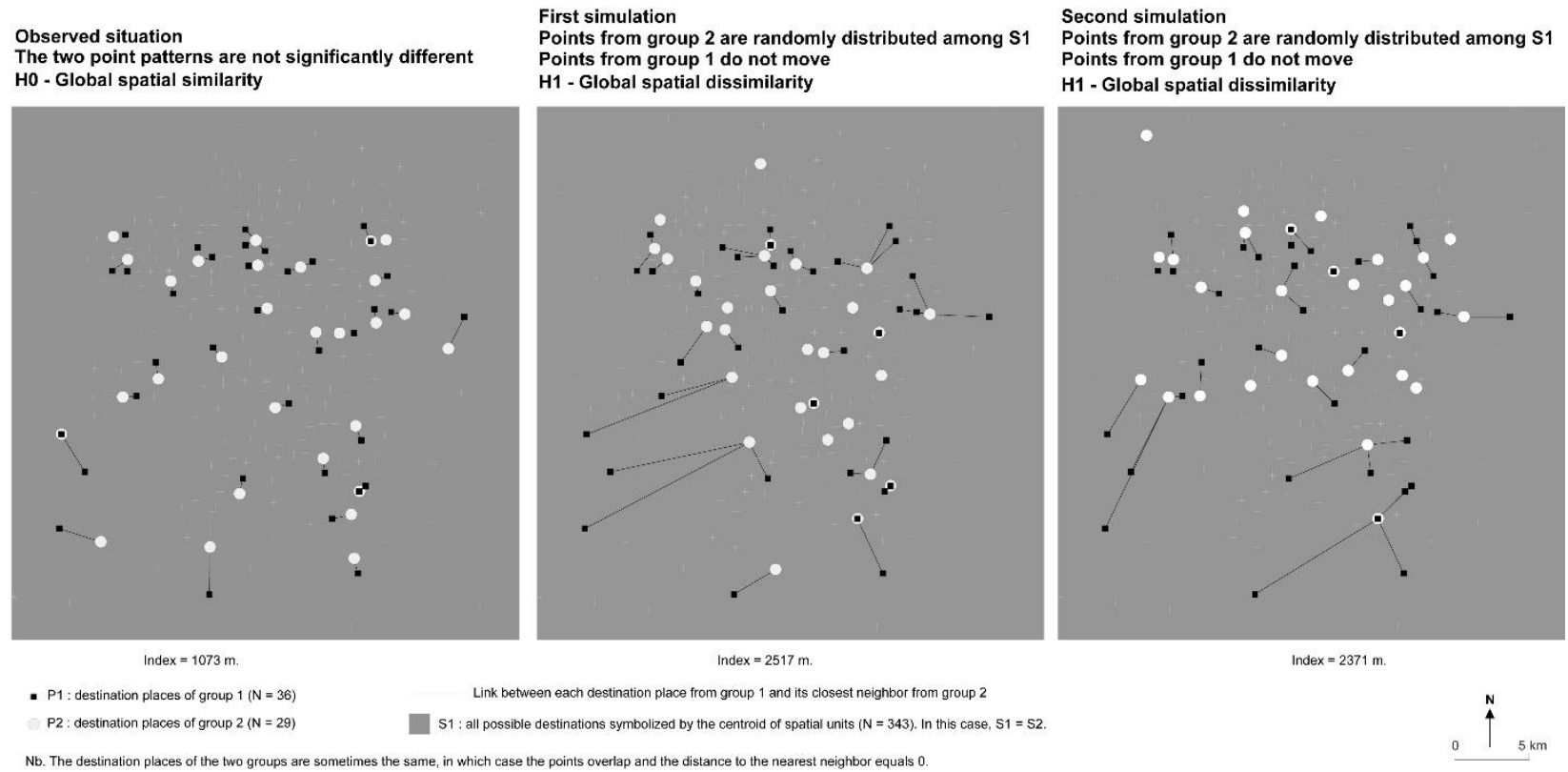

Figure 3. The principle of the bivariate colocation test - Observed situation versus simulated situations

For our analysis, we used only unilateral tests to search for dissimilarity. In this case, if the observed index is greater than the simulated indices $\left(\mathrm{I}_{\mathrm{obs}}>\mathrm{I}_{\mathrm{sim}}\right)$, the null hypothesis is rejected and HA is accepted. We compared the action spaces of pairwise groups for each of the survey zones. HA therefore means that both point patterns are significantly characterized by global dissimilarity. Six of the seven initial sociodemographic classes were retained (class $\mathrm{F}$ was discarded since either the class size or the number of destinations was too small). ${ }^{11}$ All in all, 120 tests were carried out, ${ }^{12}$ with a maximum of fifteen tests for each zone. To mitigate the problem of multiple testing (due to the fact that several tests were computed for each survey zone), a Bonferroni correction was applied, dividing the Type I risk by the number of tests for each survey zone. In the example given in table 4, the Type I risk (0.05) was divided by 10 (the number of tests). 
Table 4. Results of the colocation test comparing two by two the action spaces of the groups living in zone 05 "El Volcán" (METAL survey 2009, Santiago)

\begin{tabular}{|c|c|c|c|c|c|c|}
\hline & A & B & $\mathrm{C}$ & $\mathrm{D}$ & $\mathrm{E}$ & G \\
\hline A - Primary schoolchildren & - & & & & & \\
\hline B - Young people in studies from modest backgrounds & HO & - & & & & \\
\hline $\begin{array}{l}\text { C - Young working tenants with little education and fairly limited } \\
\text { purchasing power }\end{array}$ & HO & HO & - & & & \\
\hline D - Educated young workers with fairly high purchasing power & * & $*$ & $*$ & - & & \\
\hline E - Working property owners over forty & HA & HA & HA & $*$ & - & \\
\hline $\mathrm{F}$ - Active senior citizens & HO & HO & HO & * & HO & - \\
\hline
\end{tabular}

Example of how to read the table: groups $A$ and $B$ have action spaces that are not significantly different (H0). Groups A and E, for their part, have action spaces that are significantly different (HA).

\section{Results and discussion}

\section{Differences in action spaces: initial findings from centrographic analysis}

Visual examination of Fig. 4 yields initial findings about how groups of individuals relate to space in going to their place of work or study. Three categories of place of residence emerge:

- First category: for the four study zones in the center (zone 1 - Brasil/Yungay and zone 2 - Lira/Almagro) and inner suburbs (zone 3 - Providencia and zone 4 - Recoleta/Independencia), there seems to be little difference in the ellipses in terms both of their extent, ${ }^{13}$ and of their position (with a high overlap index, see table 5). The exception to this is class A (primary schoolchildren going to schools near their home), which stands out from the others. Furthermore, the ellipses tend to be home-centered, even though they display a certain tropism toward the north-eastern districts. In essence, in the vicinity of these four places of residence with good public transport services and good road accessibility, places of employment and study are available for all individuals, irrespective of their social-demographic class. Spatial mismatch between place of residence and place of activity is comparatively low (less than $2.7 \mathrm{~km}$ on average). ${ }^{14}$

- Second category: the ellipses for the Quilicura (zone 6) and Huechuraba (zone 7) survey zones, lying about $12 \mathrm{~km}$ north of the center, are displaced from their anchor point (survey zone). This may be explained by their location on the outer edge of the metropolitan area, and the fact that there are insufficient urban resources in the vicinity (this is especially true for employment in the Quilicura zone), obliging working people to commute to other sectors (primarily the commune in the center and a few communes lying just north of the center). ${ }^{15}$ The dissociation between place of residence and place of activity is a bit higher (6km on average). The action spaces in this second category also overlap far less (with a low overlap index for Quilicura, and an average one for Huechuraba).

Third category: the four most peripheral survey zones (zone 5 - El Volcán, zone 8 - Chicureo, zone 9 Colina, and zone 10 - Los Trapenses), lying between $20 \mathrm{~km}$ and $35 \mathrm{~km}$ from the center, have comparatively longer ellipses (with longer journeys irrespective of class, except for class A, primary schoolchildren). These are the four zones where there is the strongest mismatch between place of residence and place of activity (up to $14.3 \mathrm{~km}$ ). In addition to this, the ellipses are very clearly oriented toward the center. This may be explained both by the location of these four survey zones far from the center, and by the local shortage of employment. This confirms that these primarily residential zones are strongly dependent on the center and inner and intermediate suburbs. 


\section{Zone 1 - Brasil/Yungay}

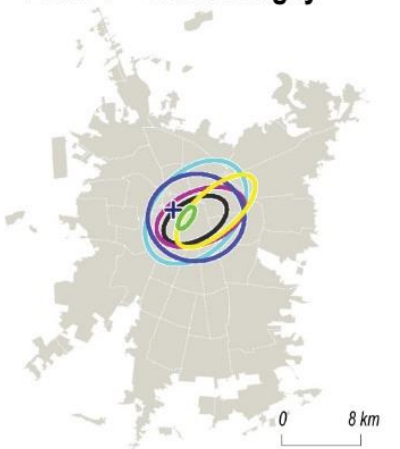

NB : Ellipse not plotted for class $F$ ( 2 individuals in this category)

\section{Zone 6 - Quilicura}

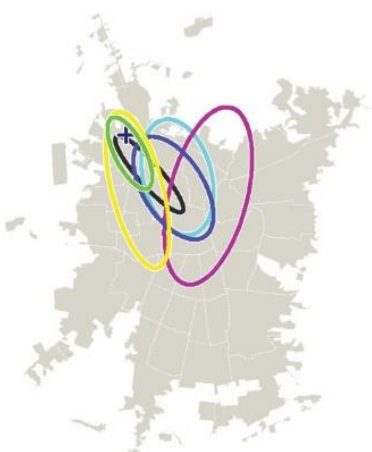

NB : Ellipse not plotted for class $F$ (no individuals in this category)

+ Survey zone (place of residence)

Communes (urbanized part)

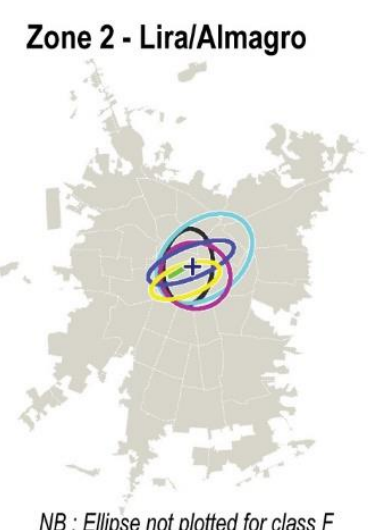

NB: Ellipse not plotted for class $F$ (no individuals in this category)

\section{Zone 7 - Huechuraba}

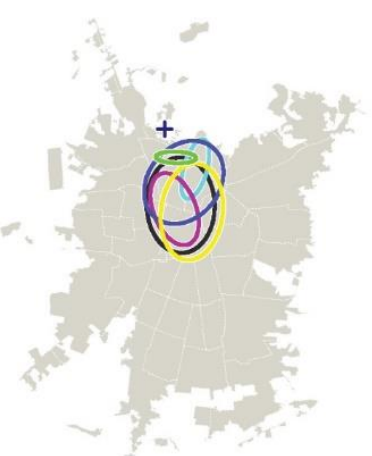

NB : Ellipse not plotted for class $F$ (4 individuals in this category)

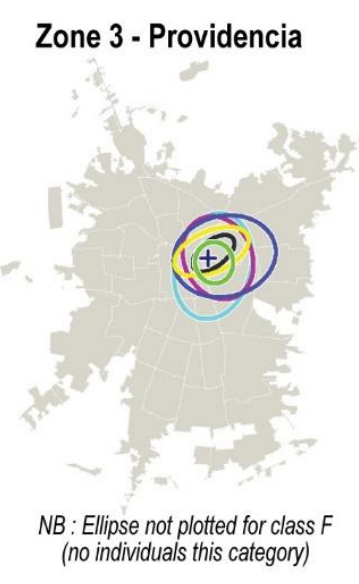

Zone 8 - Chicureo

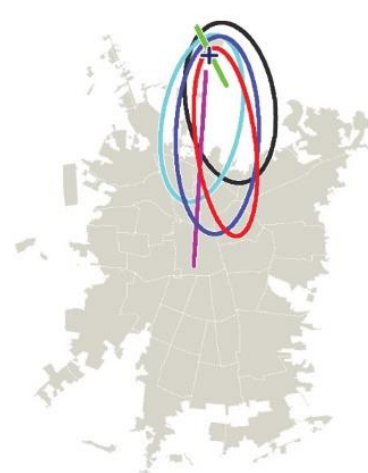

NB : Ellipse not plotted for class $G$ (4 individuals in this category)
Zone 4 - Recoleta/Independencia

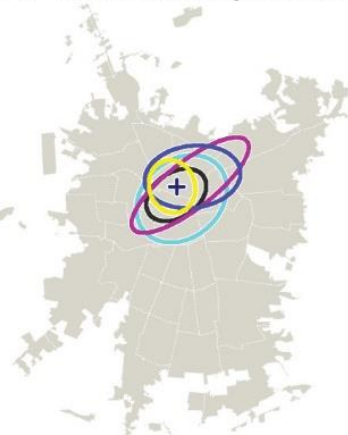

NB : Ellipse not plotted for class $F$ (no individuals in this category). Ellipse not plotted for class $A$ either (all the individuals of this category had the same destination, Recoleta, their commune of residence)

Zone 9 - Colina Tradicional

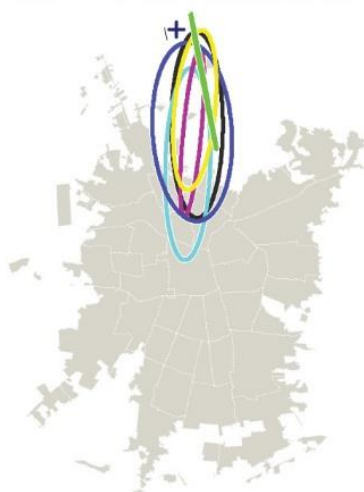

NB: Ellipse not plotted for class $F$ (no individuals in this category)

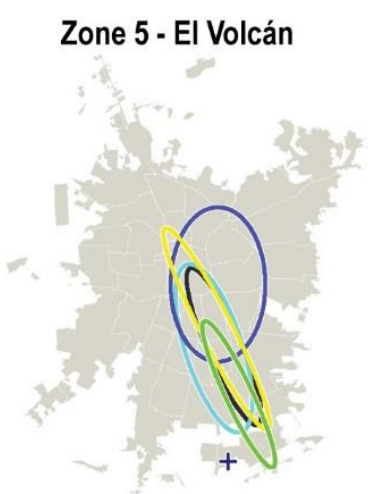

NB. Classes D and F not plotted (no individuals in these categories)

\section{Zone 10 - Los Trapenses}

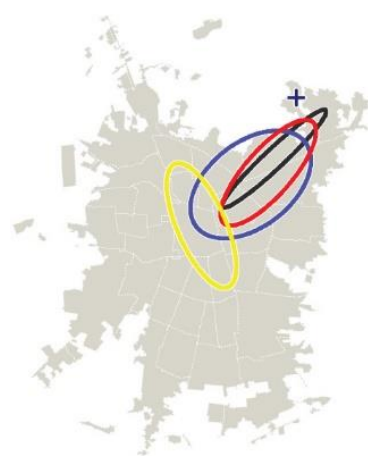

NB: Classes A, C, and D not plotted $(3,2$, and 1 individuals respectively in these categories)

- Class A: Primary schoolchildren

- Class B: Young people in studies from modest backgrounds

- Class C: Young working tenants with little education and fairly limited purchasing power

- Class D : Educated young workers with fairly high purchasing power
- Class $\mathrm{E}$ : Working property owners over forty

- Class $F:$ Wealthy individuals

- Class $\mathrm{G}$ : Working senior citizens

Figure 4. Action spaces of individuals who study or work, categorized by socio-demographic class and place of residence in Santiago de Chile (METAL survey 2009). 
Table 1. Ellipse areas and overlap indexes of action spaces by place of residence, all groups combined (METAL survey 2009, Santiago)

\begin{tabular}{|l|c|c|c|c|}
\hline \multicolumn{1}{|c|}{ Survey zone } & $\begin{array}{c}\text { A - Total area of } \\
\text { ellipses in } \mathbf{~ k m}^{\mathbf{2}}\end{array}$ & $\begin{array}{c}\text { B - Area of merged } \\
\text { ellipses in } \mathbf{~ m}^{\mathbf{2}}\end{array}$ & Ratio A/B & Overlap index \\
\hline 01 - Brasil/Yungay & 240.8 & 86.2 & 2.79 & High \\
02 - Lira/Almagro & 171.4 & 70.7 & 2.42 & High \\
03 - Providencia & 226.0 & 81.3 & 2.77 & High \\
04 - Recoleta/Independencia & 205.0 & 83.0 & 2.47 & High \\
05 - El Volcán & 333.4 & 172.1 & 1.93 & Average \\
06 - Quilicura & 334.7 & 196.5 & 1.70 & Low \\
07 - Huechuraba & 191.1 & 106.2 & 2.18 & Average \\
08 - Chicureo & 439.8 & 201.5 & 2.56 & High \\
09 - Colina & 335.4 & 131.0 & 1.56 & High \\
10 - Los Trapenses & 216.5 & 138.7 & & Low \\
\hline
\end{tabular}

\section{Statistical significance of observed differences in action spaces}

\section{Differences between places of residence}

The results of the statistical colocation tests bring out nuances within these three categories. There is thus a gradient between places of residence where a fairly large number of groups have significantly disjoint action spaces from each other, and places of residence where no significant difference transpires (Tab. 6).

Table 6. Test results of significant discrepancy between action spaces, by place of residence (METAL survey 2009, Santiago)*

\begin{tabular}{|l|c|c|c|}
\hline \multicolumn{1}{|c|}{ Survey zone } & Number of tests & Number of HA & Percentage of HA /number of tests \\
\hline 01 - Brasil/Yungay & 15 & 3 & 33.0 \\
\hline 02 - Lira/Almagro & 15 & 5 & 13.3 \\
\hline 03 - Providencia & 15 & 2 & 13.3 \\
\hline 04 - Recoleta & 10 & 2 & 20.0 \\
\hline 05 - El Volcán & 10 & 5 & 33.3 \\
\hline 06 - Quilicura & 15 & 0 & 0.0 \\
\hline 07 - Huechuraba & 15 & 0 & 0.0 \\
\hline 08 - Chicureo & 10 & 1 & 6.7 \\
\hline 09 - Colina & 15 & 3 & \\
\hline
\end{tabular}

On the one hand, in four survey zones (zones 1, 2, 5, and 6), the discrepancies between groups are relatively marked, since at least $20 \%$ of them have significantly different action spaces. For zone 5 (EI Volcán) and zone 6 (Quilicura), the results corroborate the discrepancies visible on the maps (see Fig. 4), and are consistent with the ellipse overlap index (respectively average and low, cf. table 5). But the results nuance earlier observations based on visual interpretation of the maps for zone 1 (Brasil/Yungay) and zone 2 (Lira/Almagro). Though work and study opportunities are available in the vicinity of these two places of residence for all individuals irrespective of socio-demographic class, and though the ellipses tend to 
overlap (with a high index, table 5), the test nevertheless shows that certain groups residing in the two latter zones have a significantly different way of interacting with the SMA.

On the other hand, in the three most peripheral zones (zone 7 - Huechuraba, zone 8 - Chicureo, and zone 9 - Colina), there are very few discrepancies between groups, since at most $6.7 \%$ of them have significantly different action spaces. This confirms that these primarily residential zones are fairly dependent on the center and inner and intermediate suburbs. It also confirms the degree of homogeneity in the places of destination of their inhabitants, corroborated by the ellipse overlap index (with respectively average and high indexes, cf. table 5).

\section{Differences between classes}

Turning now to discrepancies between the socio-demographic classes considered for all nine survey zones (Table 7), two classes in particular stand out. Irrespective of place of residence, the action spaces for class $\mathrm{C}$ (young working tenants with little education and fairly limited purchasing power) and for class $\mathrm{E}$ (working property owners over forty) tend to coincide less with the others, since they are significantly different in 13 and 11 instances respectively (Table 8). A potential explanation is that the number of different destinations for these two classes, in both cases 30 out of a possible maximum of 35 communes (cf. table 8), is higher than for the other classes. But this explanation was discarded because no direct correlation may be observed between the number of destinations and number of significant discrepancies $\left(R^{2}=0.44\right)$.

Table 7. Number of significant discrepancies between action spaces, for all nine survey zones (METAL survey, 2009, Santiago)

\begin{tabular}{|c|c|c|c|c|c|c|}
\hline Class & A & B & $\mathrm{C}$ & $\mathrm{D}$ & $E$ & G \\
\hline A - Primary schoolchildren & - & & & & & \\
\hline B - Young people in studies from modest backgrounds & 0 & - & & & & \\
\hline $\begin{array}{l}\text { C - Young working tenants with little education and fairly } \\
\text { limited purchasing power }\end{array}$ & 1 & 3 & - & & & \\
\hline D - Educated young workers with fairly high purchasing power & 1 & 1 & 3 & - & & \\
\hline E - Working property owners over forty & 3 & 1 & 5 & 1 & - & \\
\hline G - Working senior citizens & 0 & 0 & 1 & 0 & 1 & - \\
\hline
\end{tabular}

Table 8. Summary: number of times each socio-demographic class significantly differs with another class for all nine survey zones, and number of different destinations in the SMA by class (METAL survey 2009, Santiago)

\begin{tabular}{|l|c|c|c|}
\hline \multicolumn{1}{|c|}{ Class } & $\begin{array}{c}\text { Number of significant } \\
\text { discrepancies with another } \\
\text { class }\end{array}$ & $\begin{array}{c}\text { Number of different } \\
\text { destinations (out of 35 } \\
\text { maximum) }\end{array}$ & $\begin{array}{c}\text { Average area of } \\
\text { ellipses }\left(\mathrm{km} \mathbf{2}^{2}\right)\end{array}$ \\
\hline A - Primary schoolchildren & 5 & 14 & 8.2 \\
\hline B - Young people in studies from modest backgrounds & 5 & 25 & 4.6 \\
\hline $\begin{array}{l}\text { C - Young working tenants with little education and fairly } \\
\text { limited purchasing power }\end{array}$ & 13 & 30 & 66.3 \\
\hline $\begin{array}{l}\text { D - Educated young workers with fairly high purchasing } \\
\text { power }\end{array}$ & 6 & 23 & 42.3 \\
\hline E - Working property owners over forty & 11 & 30 & 76.3 \\
\hline G - Working senior citizens & 3 & 19 & 39.8 \\
\hline
\end{tabular}

There is thus a particularly marked spatial dissociation between place of employment for classes $\mathrm{C}$ and $\mathrm{E}$, and place of employment for other classes. Having said that, and despite this similarity, classes $C$ and $E$ are composed of individuals who are at different stages in their life, and whose daily interaction with the SMA 
pertains to two distinct situations. The singular relationship individuals from class $C$ have to the metropolitan area may be explained by the fact that they are at the beginning of their careers. Their action spaces primarily reflect access to jobs requiring few qualifications. Accessing this sort of job tends to oblige these individuals to go to a large number of places and to travel far from home (class $C$ have the secondhighest average ellipse area, covering $66.3 \mathrm{~km}^{2}$, cf. table 8). As for class $E$, composed of older individuals, the length of their journey to work is likewise long (class $E$ have the highest average ellipse area, covering $76.3 \mathrm{~km}^{2}$, cf. table 8), and they also travel to a large number of places. In this case, the marked mismatch between place of residence and place of employment may be explained by a combination of two factors: first, residential anchoring (with property owners being overrepresented in this class, as are people having lived more than twenty years in their dwelling), and second, any changes in place of work occurring over the course of their career, which may have gradually led to longer commutes.

\section{Conclusion}

This article has assessed discrepancies in how socio-demographic groups interact on a daily basis with the Santiago Metropolitan Area based on their place of residence, position in the social hierarchy, and stage in their life course. To address this issue, a three-phase integrated method has been applied to data collected to apprehend spatial mobility from a biographical perspective. Visual examination of the standard deviational ellipses synthetizing action spaces provided initial findings about how groups of individuals relate to space in going to their place of work or study. Taking into account SDE overlap, extent, and mean position, three categories of place of residence stand out, based mainly on a center-periphery rationale, with spatial mismatch increasing with distance from the inner city. The results of the bivariate colocation test brought out nuances within these three categories. There is thus a gradient between places of residence where a fairly large number of groups have significantly disjoint action spaces from each other, and places of residence where no significant difference transpires. On the one hand, the test evidenced significant spatial differences that were difficult to identify on maps or through indicators derived from centrographic analysis. This was particularly the case for the four survey zones located in the central area. On the other hand, the test did not always confirm the apparent gaps between the SDEs. This incongruence can be explained by the fact that SDEs are precisely very synthetic representations of action spaces, and that two ellipses with similar shape and position may in fact correspond to point patterns with significantly different configurations. Turning to discrepancies between the socio-demographic classes, the test identified two groups ( $\mathrm{C}$ - young working tenants with little education and fairly limited purchasing power, and $\mathrm{E}$ - working property owners over forty) who clearly stand out from the others, irrespective of their place of residence. This finding could be valuable for the next OD surveys to be carried out in Santiago. It could be used to adjust the sampling rate for these two specific groups in order to expand the results more accurately. More empirical studies are needed to verify if this situation also arises in other cities and to identify which socio-demographic groups are concerned. Our next step will therefore be to apply the same methodology to similar spatial mobility surveys carried out as part of the same ANR-funded METAL program in 2009 in two other Latin American cities (Bogotá and São Paulo). In the case of Santiago, this article shows that, apart from for groups $C$ and $E$, there are ultimately no systematic discrepancies - that is to say, there is no clearly established socio-spatial determinism in places frequented for work and study on a daily basis, even in a segregated and polycentric city in Latin America.

Furthermore, from a methodological point of view, the bivariate colocation test could provide a convenient way of analyzing the significance of discrepancies between activity spaces in many other domains. One of the first applications which comes to mind is obviously linked to segregation or discrimination. Indeed, the test could be used to identify social groups that experience noteworthy inequalities in access to healthcare or education, for instance. Moreover, in a diachronic perspectivesuch as the time span between two OD surveys - this kind of analysis could be used to ascertain whether people have experienced a meaningful improvement in their access to urban resources, or whether 
connections between peripheral neighborhoods and economic districts have become significantly better. This would make it possible to monitor, among other things, the effectiveness of local public transport policies.

\section{Appendix: the bivariate colocation test formula}

Suppose two sets of points $U$ and $V$, formally corresponding to two fields of random variables $f: U \rightarrow \mathbb{R}$ and $g: V \rightarrow \mathbb{R}$ whose realization is known. When the functions $f$ and $g$ are Boolean, a set-based approach can be used, each function defining a subset ( $U^{\prime}$ of $U$ and $V^{\prime}$ of $V$ ) corresponding to the points Pi whose value is 1 (positive marks). The index ST is calculated with the following equation which gives the mean of distances $\operatorname{DNN}\left(\mathrm{P}, \mathrm{U}^{\prime}\right)$, for all the points $\mathrm{P}$ of $\mathrm{V}^{\prime}$.

$$
\begin{gathered}
\mathrm{ST}(\mathrm{d} 0)=\frac{1}{n 2} \sum_{n 2} f(P i) \forall P i \in V^{\prime} \text {, with } f(P i)=\left(D N N\left(P i, U^{\prime}\right)\right)^{m} \\
\text { if } D N N\left(P i, U^{\prime}\right)<\mathrm{d} 0 \text { and } f(P i)=0 \text { otherwise }
\end{gathered}
$$

where $D N N\left(P_{i}, U^{\prime}\right)$ designates the distance between point $\mathrm{P}_{\mathrm{i}}$ of $\mathrm{V}^{\prime}$ and its nearest neighbor in $\mathrm{U}^{\prime}, \mathrm{n} 2$ is the number of points of $V^{\prime}$, and $d 0$ is the exclusion distance beyond which there is no reason to search for interactions between the two phenomena. The value of $m(1 / 2,1$ or 2$)$ is used to adjust the absolute influence of distance.

\section{References}

Aguiléra, A., and D. Mignot. (2002). "Structure des localisations intra-urbaines et mobilité domicile-travail." Recherche - Transports - Sécurité 77, 311-325. https://doi.org/10.1016/S0761-8980(02)90006-3

Alsnih, R. and D.A. Hensher. (2003). "The Mobility and Accessibility Expectations of Seniors in an Aging Population." Transportation Research A 37, 903-916. https://doi.org/10.1016/S0965-8564(03)00073-9

Antico, C. (2003). Onde morar e onde trabalhar: espaço e deslocamentos pendulares na região metropolitana de São Paulo. PhD. Thesis in demography, Universidade Estadual de Campinas.

Åslund, O., and O. N. Skans. (2010). "Will I see you at work? Ethnic workplace segregation in Sweden, 1985-2002." Industrial and Labor Relations Review 63(3), 471-493. https://doi.org/10.1177/001979391006300306

Atkinson, R., and J. Flint. (2004). "Fortress UK? Gated communities, the spatial revolt of the elites and time-space trajectories of segregation." Housing Studies 19(6), 875-892. DOI: 10.1080/0267303042000293982

Baccaïni, B., Semecurbe, F., And G. Thomas. (2007). Les déplacements domicile-travail amplifiés par la périurbanisation. Paris, Insee. http://www.insee.fr/fr/ffc/ipweb/ip1129/ip1129.pdf

Bachi, R. (1963). "Standard distance measure and related methods for spatial analysis." Papers in Regional Sciences 10(1), 73-132.

Bassand, M., and M.-C. Brulhardt. (1980). Mobilité spatiale. Bilan et analyse des recherches en Suisse. Lausanne, Ed. Georgi.

Berger, M., (2004). Les périurbains de Paris. Paris, CNRS éditions, Espaces et Milieux.

Borsdorf, A. (2003). "Hacia la ciudad fragmentada. Tempranas estructuras segregadas en la ciudad latinoamericana." Scripta Nova. Revista electrónica de geografía y ciencias sociales 7(146). http://www.ub.edu/geocrit/sn/sn-146\%28122\%29.htm

Buliung, R. N., and P.S. Kanaroglou. (2006). "Urban form and household activity-travel behavior." Growth \& Change 37(2), $172-199$. https://doi.org/10.1111/j.1468-2257.2006.00314.x

Camstra, R. (1994). "The Geodemography of Gender: Spatial Behaviour of Working Women." Tijdschrift voor Economische en Sociale Geografie 85, 434-445. https://doi.org/10.1111/j.1467-9663.1994.tb00702.x

Camstra, R. (1996). "Commuting and Gender in a Lifestyle Perspective." Urban Studies 33, $283-300$. https://doi.org/10.1080/00420989650012013

Carman, M., Vieira da Cunha, N., and R. Segura. (2013). Segregación y diferencia en la ciudad. Quito: FLACSO.

Capron, G., and S. González Arellano. (2006). "Las escalas de la segregación y de la fragmentación urbana." TRACE 49, 65-75. http://www.redalyc.org/articulo.oa?id=42383950500 
Cervero, R., and K.L. Wu. (1997). "Polycentrism, Commuting, and Residential Location in the San Francisco Bay Area." Environment and Planning A 29, 865-886. https://doi.org/10.1068/a290865

Contreras, Y. (2011). "La recuperación urbana y residencial del centro de Santiago: Nuevos habitantes, cambios socioespaciales significativos." Eure 37(112), 89-113. http://www.scielo.cl/scielo.php?script=sci_arttext\&pid=S0250$71612011000300005 \& \operatorname{lng}=e s \&$ tlng=es

Contreras, Y., Ala-Louko, V., and G. Labbé. (2016). "Acceso exclusionario y racista a la vivienda formal e informal en las áreas centrales de Santiago e Iquique." Polis, 14(42), 1-18. http://www.redalyc.org/articulo.oa?id=30544552004

Cosacov, N. (2015). "Más allá de la vivienda: los usos de la ciudad: movilidad cotidiana de residentes en Buenos Aires." Estudios Socioterritoriales 18, 61-80. https://ri.conicet.gov.ar/handle/11336/70682

Courgeau, D. (1988). Méthodes de mesure de la mobilité spatiale. Paris, Éditions de l'INED.

Cullen, I., and V. Godson. (1975). "Urban networks: the structure of activity patterns." Progress in Planning 4(1), 1-96. https://doi.org/10.1016/0305-9006(75)90006-9

Delaunay, D. (2010). "Mobilités, ségrégations résidentielles et bonus démographique dans la zone métropolitaine de Santiago du Chili." Revue Tiers Monde 201, 65-85. https://doi.org/10.3917/rtm.201.0065

Delaunay, D., Contreras, Y., and J.M. Fournier. (2013). “¿Es posible medir el capital de movilidad para evaluar sus diferenciaciones sociodemográfica e intraurbana? El caso de los habitantes del Área Metropolitana de Santiago de Chile." Estudios Demográficos y Urbanos 28(1), 9-51. http://www.redalyc.org/articulo.oa?id=31230009001

Demoraes, F., Contreras, Y., and M. Piron. (2016). “Localización residencial, posición socioeconómica, ciclo de vida y espacios de movilidad cotidiana en Santiago de Chile." Revista Transporte y Territorio, 274-301. https://hal.archives-ouvertes.fr/hal-01401945

Demoraes, F., Dureau, F. and M. Piron. (2011). Análisis comparativo de la segregación social en Bogotá, Santiago y São Paulo. Paris, documento de trabajo ANR METAL. https://hal.archives-ouvertes.fr/hal-01284604

Demoraes, F., Gouëset, V., and M. Bouquet. (2019). "Mesurer l'évolution de l'accessibilité à l'aide des espaces-temps d'action : l'exemple de Bogotá entre 1993 et 2009." Cybergeo: European Journal of Geography 926, 1-36. https://doi.org/10.4000/cybergeo.33638

Demoraes, F., Gouëset, V., and M. Bouquet. (2018). "Comparaison des mobilités quotidiennes adultes/enfants à travers la métrique des espaces-temps d'action : intérêt, limites, méthode et cartes - L'exemple de Bogotá (Colombie)." 16ème colloque MSFS Mobilités spatiales, méthodologies de collecte, d'analyse et de traitement, Tours. https://hal.archives-ouvertes.fr/hal-02019868

Demoraes, F., Gouëset, V., Piron, M., Figueroa, O., and S. Zioni. (2010). "Mobilités quotidiennes et inégalités socio-territoriales à Bogotá, Santiago du Chili et São Paulo." Espace, Populations, Sociétés 2, 349-364. https://doi.org/10.4000/eps.4218

Demoraes, F., Piron, M., Zioni, S., and S. Souchaud. (2012). "Inégalités d'accès aux ressources de la ville analysée à l'aide des mobilités quotidiennes - Approche méthodologique exploratoire à São Paulo." Cahiers de géographie du Québec 56(158), 463-489. https://doi.org/10.7202/1014555ar

Depeau, S. (2001). "Urban Identities and Social Interaction: a cross-cultural analysis of young people's spatial mobility in Paris, France and Frankston, Australia." Local Environment 6(1), 81- 86.

Dijst, M. (1999). "Two-earner families and their action spaces: A case study of two Dutch communities." GeoJournal 48, 195-206.

Janelle, D., and M. Goodchild. (1983). "Diurnal patterns of social group distribution in Canadian cities." Economic Geography, 59(4), 403-425. http://www.spatial.ucsb.edu/janelle/docs/Diurnal-Janelle-Goodchild-1983.pdf

Dureau, F. (2006). "Habiter la ville : stratégies et mobilités résidentielles." In: Dureau, F., Gouëset, V. and E. Mesclier. Géographies de l'Amérique latine. Presses Universitaires de Rennes, coll. Espace et territoires, 263-292.

Dureau, F., Barbary, O., Michel, A., and B. Lortic. (1989). Sondages aréolaires sur image satellite pour des enquêtes sociodémographiques en milieu urbain. Paris, Edition Orstom. http://horizon.documentation.ird.fr/exldoc/pleins_textes/pleins_textes_7/divers2/30031.pdf

Dureau, F., Contreras, Y., Cymbalista, R., Le Roux, G. and M. Piron. (2015a). "Evolución de la intensidad y de las escalas de la segregación residencial desde los años 1990: un análisis comparativo". Chap. 4 in Dureau, F., Lulle, T., Souchaud, S., and Y. Contreras. (2015). Movilidades y cambio urbano. Bogotá, Santiago y São Paulo. Universidad Externado de Colombia, 127-156.

Dureau, F., Giroud, M., and C. Imbert. (2015b). "Event history approach to life spaces in French-speaking research". In Worth, N., and I. Hardill. Researching the life course. Critical reflections from the social sciences, Policy press, 215-231. https://hal-upecupem.archives-ouvertes.fr/hal-01172546 
Dureau, F., Lulle, T., Souchaud, S., and Y. Contreras. (2015c). Movilidades y cambio urbano. Bogotá, Santiago y São Paulo. Bogotá, Universidad Externado de Colombia.

Ellis, M., Wright, R., and V. Parks. (2004). "Work Together, Live Apart? Geographies of Racial and Ethnic Segregation at Home and at Work." Annals of the Association of American Geographers 94(3), 620-637. https://doi.org/10.1111/j.1467-8306.2004.00417.x

Farber, S., Paez, A., and C. Morency. (2012). "Activity spaces and the measurement of clustering and exposure: A case study of linguistic groups in Montreal." Environment and Planning A 44, 315-332, https://doi.org/10.1068/a44203

Farber, S., O'kelly, M., Miller, H. J., and T. Neutens. (2015). “Measuring segregation using patterns of daily travel behavior: A social interaction-based model of exposure." Journal of Transport Geography 49, 26-38. https://doi.org/10.1016/j.jtrangeo.2015.10.009

Föbker, S., and R. Grotz. (2006). "Everyday mobility of elderly people in different urban settings: The example of the City of Bonn, Germany." Urban Studies 43(1), 99-118. https://doi.org/10.1080/00420980500409292

Giuliano, G., and K.A. Small. (1993). “Is the Journey to Work Explained by Urban Structure?” Urban Studies 30 (9), $1485-1500$. https://doi.org/10.1080/00420989320081461

Golledge, R. G., and R.J. Stimson. (1997). Spatial behavior: A geographic perspective. The Guilford Press.

Gordon, P., Kumar, A., and W. Richardson. (1989). "The Influence of Metropolitan Spatial Structure on Commuting Time." Journal of Urban Economics 26, 138-151. https://doi.org/10.1016/0094-1190(89)90013-2

Gouëset, V., Demoraes, F., Figueroa, O., Le Roux, G., and S. Zioni. (2015). "Recorrer la metrópoli. Prácticas de movilidad cotidiana y desigualdades socio-territoriales." Chap. 8, in Dureau, F., Lulle, T., Souchaud, S., and Y. Contreras. Movilidades y cambio urbano. Bogotá, Santiago y São Paulo. Bogotá, Universidad Externado de Colombia, 303-344. https://hal.archives-ouvertes.fr/hal-01282075

Hernández, D. (2012). "Activos y estructuras de oportunidades de movilidad. Una propuesta analítica para el estudio de la accesibilidad por transporte público, el bienestar y la equidad." Eure 38(115), 117-135. https://www.eure.cl/index.php/eure/article/view/114/582

Horton, F., and D.R. Reynolds. (1971). "Effects of urban spatial structure on individual behaviour." Economic Geography 47(1), 3648. https://doi.org/10.2307/143224

Imbert, C., Dureau, F., and M. Giroud. (2009). "Méthodes d'analyse des mobilités urbaines des ménages : réflexions autour de I'enquête Déplacements Poitiers." In Macchi, J. (Eds). Geografie del popolamento, Casi di studio, metodi e teorie. pp. 89-96.

Hirsch, J., Winters, M., Clarke, P. and H. McKay. (2014). "Generating GPS activity spaces that shed light upon the mobility habits of older adults: a descriptive analysis." International Journal of Health Geographics, 13-51. https://doi.org/10.1186/1476-072X-13-51

Järv, O., Müürisepp, K., Ahas, R., Derudder, B., and F. Witlox. (2015). "Ethnic differences in activity spaces as a characteristic of segregation: A study based on mobile phone usage in Tallinn, Estonia." Urban Studies 52(14), 2680-2698. https://doi.org/10.1177/0042098014550459

Jirón, P. (2009). "Prácticas de movilidad cotidiana urbana. Un análisis para revelar desigualdades en la ciudad." In PÉREZ OYARZUN, F., and M. TIRONI RODÓ (comps.), SCL: espacios, prácticas y cultura urbana. Santiago de Chile: Ediciones ARQ, 176-189. http://repositorio.uchile.cl/handle/2250/118192

Jirón, P., Lange, C., and M. Bertrand. (2010). “Exclusión y desigualdad espacial: Retrato desde la movilidad cotidiana." INVI 25(68), 15-57. https://doi.org/10.4067/S0718-83582010000100002

Jones, M., and A. Pebley. (2014). "Redefining neighborhoods using common destinations: Social characteristics of activity spaces and home census tracts compared" Demography 51, 727-752. https://doi.org/10.1007/s13524-014-0283-z

Jouffe, Y. (2011). "Las prácticas cotidianas frente a los dispositivos de la movilidad. Aproximación política a la movilidad cotidiana de las poblaciones pobres periurbanas de Santiago de Chile." Eure 36(108), 29-47. http://doi.org/10.4067/S025071612010000200002

Kilroy, A. (2007). Intra-urban spatial inequality: Cities as "urban regions", Reshaping Economic Geography, World Development Report 2009. http://siteresources.worldbank.org/INTWDR2009/Resources/4231006-1204741572978/Kilroy2.pdf

Kwan, M.P., Wang, J., Tyburski, M., Epstein, D., Kowalczyk, W., and K. Preston. (2019). "Uncertainties in the geographic context of health behaviors: A study of substance users' exposure to psychosocial stress using GPS data." International Journal of Geographical Information Science 33(6), 1176-1195. https://doi.org/10.1080/13658816.2018.1503276

Lanzendorf, M. (2003). "Mobility biographies. A new perspective for understanding travel behavior." Conference paper. 10th International Conference on Travel Behaviour Research. Moving through nets: The physical and social dimensions of travel, Lucerne, 10-15. 20p. 
Le Roux, G., Vallée, J., and H. Commenges. (2017). "Social segregation around the clock in the Paris region (France)." Journal of Transport Geography 59, 134-145. https://doi.org/10.1016/j.jtrangeo.2017.02.003

Lefever, D. W. (1926). "Measuring geographic concentration by means of the standard deviation ellipse." American journal of sociology 32(1), 88-94. https://www.jstor.org/stable/2765249

Lévy, J.-P., and F. Dureau. (2002). L'accès à la ville. Les mobilités spatiales en questions. Paris, L'Harmattan, Coll. Habitat et sociétés.

Li F., and D. Wang. (2017) "Measuring urban segregation based on individuals' daily activity patterns: A multidimensional approach." Environment and Planning A. 49(2), 467-486. https://doi.org/10.1177/0308518X16673213

Park, Y.M., and M.P. Kwan. (2018). "Beyond residential segregation: A spatiotemporal approach to examining multi-contextual segregation." Computers, Environment and Urban Systems 71, 98-108. https://doi.org/10.1016/j.compenvurbsys.2018.05.001

Pérez López, R., and G. Capron. (2018). "Movilidad cotidiana, dinámicas familiares y roles de género: análisis del uso del automóvil en una metrópoli latinoamericana." $\quad$ Quid $\quad 16 \quad 10,128$. https://publicaciones.sociales.uba.ar/index.php/quid16/article/view/2904

Lord, S., Joerin, F., and M. Thériault. (2009). "Évolution des pratiques de mobilité dans la vieillesse : un suivi longitudinal auprès d’un groupe de banlieusards âgés."Cybergeo, 20p. http://cybergeo.revues.org/22090

Lord, S., Després, C., and T. Ramadier. (2011). "When mobility makes sense: A qualitative and longitudinal study of the daily mobility of the elderly." Journal of Environmental Psychology 31(1), 52-61. https://doi.org/10.1016/j.jenvp.2010.02.007

Lungo, M., and S. Baires. (2001). "Socio-Spatial Segregation and Urban Land Regulation in Latin American Cities." proceeding of the International Seminar on Segregation in the City, the Lincoln Institute, 22 p. http://citeseerx.ist.psu.edu/viewdoc/download?doi=10.1.1.200.8130\&rep=rep1\&type=pdf

Morency, C., Paez, A., Roorda, M., Mercado, R. and S. Farber. (2011). "Distance traveled in three Canadian cities: Spatial analysis from the perspective of vulnerable population segments." Journal of Transport Geography 19(1), 39-50. https://doi.org/10.1016/j.jtrangeo.2009.09.013.

Moreno, C. (2016). "Segregación en el espacio urbano de Soacha. ¿Transmilenio como herramienta integradora?" Revista de Arquitectura 18(1), 48-55. URL: http://doi.org/10.14718/RevArq.2016.18.1.5

Palmer, J.R.B. (2013). Activity-space segregation: Understanding social divisions in space and time. Doctoral dissertation, Princeton University.

Parthasarathi, P., Hochmair, H., and D. Levinson. (2015). "Street network structure and household activity spaces." Urban Studies 52(6), 1090-1112. https://doi.org/10.1177/0042098014537956

Patterson, Z., and S. Farber (2015). "Potential Path Areas and Activity Spaces in Application: A Review." Transport Reviews 35(6), 679-700. http://doi.org/10.1080/01441647.2015.1042944

Prévôt Schapira, M.F. (2000). "Segregación, fragmentación, secesión. Hacia una nueva geografía social en la aglomeración de Buenos Aires." Economía, Sociedad y Territorio 2(7), 405-431. https://www.redalyc.org/pdf/111/11100702.pdf

Quiroga, P. (2014). Mobilités urbaines, pratiques résidentielles et inégalités. Le cas des personnes âgées pauvres à Récife (Brésil). PhD Thesis, Université Rennes 2. https://hal.archives-ouvertes.fr/tel-01104684

Rai, R.K., Balmer, M., Rieser, M., Vaze, V.S., Schönfelder, S., and K.W. Axhausen. (2007). "Capturing human activity spaces: New geometries." Transportation Research Record 2021, 70-80. https://doi.org/10.3141/2021-09

Raine, J. (1978). "Summarizing Point Patterns with the Standard Deviational Ellipse." Area 10(5), $328-333$. http://www.jstor.org/stable/20001388

Rapoport, A. (2005). "On using "home" and "place". In Rowles, G.D., and H. Chaudhury. (Eds.). Home and Identity in Late Life: International Perspectives. Springer Publishing Company, New York, pp. 343--360. https://www.questia.com/library/119412902/home-and-identity-in-late-life-international-perspectives

Rodríguez, J. (2008). "Movilidad cotidiana, desigualdad social y segregación residencial en cuatro metrópolis de América Latina." Eure 34(103), 49-71. http://doi.org/10.4067/S0250-71612008000300003

Rodriguez, J., and C. Arriagada. (2004). "Segregación residencial en la Ciudad Latinoamericana." Eure 30(89), 5-24. http://dx.doi.org/10.4067/S0250-71612004008900001

Rodríguez, J. (2007). "Segregación residencial, migración y movilidad espacial. El caso de Santiago de Chile." Cuadernos metrópole 17, 135-168. https://revistas.pucsp.br/metropole/article/view/8768 
Sabatini, F., Cáceres, G., and J. Cerda. (2001). "Residential segregation pattern changes in main Chilean cities: scale shifts and increasing malignancy." International Seminar on Segregation in the City, Lincoln Institute of Land Policy, Cambridge, Mass.

Scheiner, J., and C. Holz-Rau. (2013). "Changes in travel mode use after residential relocation: a contribution to mobility biographies." Transportation 40(2), 431-458. https://doi.org/10.1007/s11116-012-9417-6

Schnell, I., and B. Yoav. (2001). "The Sociospatial Isolation of Agents in Everyday Life Spaces as an Aspect of Segregation." Annals of the Association of American Geographers 91(4), 622-636. https://doi.org/10.1111/0004-5608.00262

Schönfelder, S., and K. Axhausen. (2002). "Measuring the size and structure of human activity spaces. The longitudinal perspective." Working Paper, ETH Collection, Zurich, 50p. https://www.research-collection.ethz.ch/handle/20.500.11850/36482

Schönfelder, S., and K. Axhausen. (2003). "Activity spaces: Measures of social exclusion?" Transport Policy 10, $273-286$. https://doi.org/10.1016/j.tranpol.2003.07.002

Schteingart, M. (2001). "La división social del espacio en las ciudades." Perfiles Latinoamericanos 19, 13-31. https://perfilesla.flacso.edu.mx/index.php/perfilesla/article/view/314

SECTRA (1991). Encuesta Origen Destino de Viajes del Gran Santiago, Informe final, Ministerio de Planificación (MIDEPLAN), Comisión de Planificación de Inversiones en Infraestructura de Transporte, 340 p. + appendices (780р.).

SECTRA (2006). Actualización y Recolección de Información del Sistema de Transporte Urbano, Ministerio de Planificación (MIDEPLAN), Pontificia Universidad Católica de Chile (Dirección de Investigaciones Científicas y Tecnológicas), 557 p.

Segura, R. (2012). "Elementos para una crítica de la noción de segregación residencial socio-económica. Desigualdades, desplazamientos e interacciones en la periferia de La Plata." Quid $16 \quad 2$, $106-132$. https://dialnet.unirioja.es/descarga/articulo/5593361.pdf

Silm, S., and R. Ahas. (2014). "Ethnic Differences in Activity Spaces: A Study of Out-of-Home Nonemployment Activities with Mobile Phone Data." Annals of the Association of American Geographers 104, 542-559. https://doi.org/10.1080/00045608.2014.892362

Simpson, W. (1987). "Workplace Location, Residential Location, and Urban Commuting." Urban Studies 24, 119-128. https://doi.org/10.1080/713703872

Souris, M. (2019). Epidemiology and Geography. Principles, Methods and Tools of Spatial Analysis, Wiley, 280 p., https://doi.org/10.1002/9781119528203

Souris, M. and L. Bichaud. (2011). "Statistical methods for bivariate spatial analysis in marked points. Examples in spatial epidemiology." Journal of Spatial and Spatio-temporal Epidemiology 2(4), 227-234. https://doi.org/10.1016/j.sste.2011.06.001

Suárez, M., Murata, M., and J.D. Campos. (2016). "Why do the poor travel less? Urban structure, commuting and economic informality in Mexico City." Urban Studies 53(12), 2548-2566. https://doi.org/10.1177/0042098015596925

Vich, G., Marquet, O., and C. Miralles-Guasch. (2017). «Suburban commuting and activity spaces: using smartphone tracking data to understand the spatial extent of travel behaviour." The Geographical Journal 183(4), 426-439. https://doi.org/10.1111/geoj.12220

Von Dürckheim, K. (1932). "Untersuchungen zum gelebten Raum." in Neue psychologische Studien, 383-480, edited by F. Krueger. Munich: C.H. Beck'sche Verlagsbuchhandlung

Wang, D., Li, F. and Y. Chai. (2012). “Activity Spaces and Sociospatial Segregation in Beijing." Urban Geography 33(2), 256-277, https://doi.org/10.2747/0272-3638.33.2.256

Wegener, M. (2011). "The IRPUD model." Working Paper 11/01. Dortmund, Germany: Spiekermann \& Wegener Urban and Regional Research, 56 p. http://www.spiekermann-wegener.de/mod/pdf/AP_1101_IRPUD_Model.pdf

Wong, D. W. S., and S.-L. Shaw. (2011). "Measuring segregation: An activity space approach.” Journal of Geographical Systems 13 (2), 127-145. https://doi.org/10.1007/s10109-010-0112-x

Zhang, X., Wang J., Kwan M.-P., and Y. Chai. (2019). "Reside nearby, behave apart? Activity-space-based segregation among residents of various types of housing in Beijing, China." Cities 8, 166-180. https://doi.org/10.1016/j.cities.2018.10.009

Zelinsky, W. (1971). "The hypothesis of the mobility transition." Geographical review 61(2), $219-249$. https://doi.org/10.2307/213996 


\section{Notes}

${ }^{1}$ Groupe de Réflexion sur l'Approche Biographique (Reflection Group on the Biographical Approach), led by the Institut national d'études démographiques (French National Institute of Demographic Studies).

${ }^{2}$ According to INE: Instituto Nacional de Estadísticas (Chilean National Institute of Statistics).

${ }^{3} \mathrm{The} \mathrm{SCl}$ is a synthetic indicator that has been widely used in Latin America since the early 1990s to represent household income. It is described in Dureau et al., 2015, p.73. It is calculated by dividing the average number of years of study of household members aged fifteen and over by the average number of people per room in the dwelling. Classes 1 and 6 correspond respectively to the poorest $10 \%$ of households and the richest $10 \%$; classes 2 and 5 correspond to the following $15 \%$, while classes 3 and 4 to the $25 \%$ of households on either side of the median.

${ }^{4}$ The acronym METAL stands for "Métropoles d'Amérique latine dans la mondialisation : reconfigurations territoriales, mobilité spatiale, action publique" (Latin American metropolises in globalization: territorial reconfigurations, spatial mobility, public action). This program funded by the ANR (the French National Research Agency) was headed by Françoise Dureau (IRD - MIGRINTER research unit, UMR 7301 CNRS - Université de Poitiers).

${ }^{5}$ Also called hierarchical agglomerative clustering.

${ }^{6}$ The decision to keep seven classes is based on a compromise between being able to significantly structure the population under study, while having large enough classes to be able to calculate the ellipses and apply the significance test.

7 The tool used to calculate the standard deviational ellipses was SavGIS (http://www.savgis.org/SavGIS/accueil.html).

8 On several occasions, the people entering the information into the database encountered difficulties with the commune codes noted by the interviewers on the questionnaires. Some codes were incomplete, incorrect, or unreadable.

9 There were only six cases beneath this threshold. This threshold was chosen on the basis of the number of individuals per group (average group size: 24 , maximum group size: 101).

${ }^{10}$ The formal equation of the formula of this index is given in an appendix.

${ }^{11}$ Zone 10 (Los Trapenses) was also excluded, since most of the groups there had less than five members or else the number of destinations was too small.

12 The tests were performed using SavGIS. The number of tests per zone is given in table 6 . The number of tests is obtained as follows: (6 classes $x 6$ classes -6 classes) $/ 2$.

${ }^{13}$ The sum of the areas of the ellipses for all classes combined is broadly similar from one zone to the other, ranging from $171 \mathrm{~km}^{2}$ to $240 \mathrm{~km}^{2}$ (Table 5 ).

${ }^{14}$ Euclidean distance between place of residence and centroid of the ellipses (average per zone).

${ }^{15}$ Only $21 \%$ of the working people surveyed in the Quilicura study zone worked in their commune of residence. 